\title{
COMMUNITY CIRCLE AS A TEACHING STRATEGY FOR THE DEVELOPMENT OF PROSOCIAL DIALOGUE IN A FAMILY- TYPE PRIMARY SCHOOL
}

\section{Michaela Pachelová ${ }^{1}$}

${ }^{1}$ Charles University in Prague, Czech Republic

\author{
Eduport 5 (2) - Reviewed Papers \\ DOI: 10.21062/edp.2021.008
}

\begin{abstract}
Aims: The case exploratory study, the subject of which are the teaching strategies of four respondents, is focused on the analysis of the activity of the community circle supporting communicative skills at the 1st stage of a family-type primary school in the context of teaching prosociality. The prosociality program according to PROT is compared with the support of the acquisition of communicative skills. The aim of the case study was to characterize how the processes of communication development in the community circle are managed in the school in the teaching of ethical education based on the observations of the 4th and 5th grade and interviews with four teachers who teach in the classroom. The research is accompanied by a description of the environment in which the observation and data collection took place. Methods: Observation, semi-structured individual interviews with teachers and content analysis of teaching artifacts. The segmented data were analyzed with the intention of comparing the congruence of teachers' strategies with the implemented teaching. Conclusion: Teachers expressed that they strategically include the activity of communication in a circle, which in their opinion develops the ability to listen and share their knowledge with the class team with confidence. In accordance with the expressed teaching strategies with observation, teachers organize a space for the development of communicative skills in the context of prosociality. He tries to support mutual communication between classmates throughout the day. Targeted development of communication skills in the context of prosociality took place in community circle during the final evaluation, recommendations and peer learning.
\end{abstract}

Keywords: prosocial education, communicative skills, teacher strategy, community circle

\section{INTRODUCTION}

The development of prosocial communication and emotional intelligence in the context of ethical education (hereinafter EtE) at present creates for pupils an environment of self-knowledge and closer familiarization with peers. It offers a space for communication and brings a sense of belonging and security at school. Interpersonal relationships and communication are the first, thus the basic step, of the educational program EtE that takes place within the gradual acquisition of individual social skills. According to research by the Czech School Inspectorate (2016), school headmasters do not include EtE due to lack of available hours and teacher training. Schools set their own goals for EtE and how much space they dedicate to the development of pupils' prosocial skills. Communication is a way to coexistence and understanding with another person and can only take place in an atmosphere of mutual acceptance and recognition (Podmanický, Rajský, 2016, p. 141). We are relational, interdependent beings. We can reshape or break relationships, however, some remain part of our identity (Rajský, 2019, p. 128). The key to understanding is listening and communication, where pupils implement prosocial behavior. Prosocial Optimization Theory (PROT) is derived from studies carried out at the Faculty of Psychology of the University of Barcelona. The theory follows the research and methodologies of the implemented teaching of the psychology study program during the years 1982 to 2021 . The theoretical- 
practical model of PROT, which is based on the definition of prosociality, was also defined. The definition develops on three levels: it is a theoretical level - the content of the term prosociality (Roche 1992, 2005), the level of definition of 10 operational categories (Roche 1992, 2005), and then as a methodology defining 10 categories for all differentiated contexts (Escotorín, Roche, 2011). In the perspective of the transfer of the PROT model, it is proposed to define prosociality in close connection with a strong communicative, participatory, and dyadic component. Roche $(1992,2003)$ introduces the theory and distinguishes prosocial behavior as physical help and service, gifts, verbal help or encouragement, positive evaluation of others, emphatic verbal and nonverbal expression of understanding the speakers' emotions based on experiencing feelings similar to theirs, solidarity, and positive personal presence.

With her research, Stará (2011) points out the importance of conscious targeting of education. The purpose of the implementation of the complementary field of EtE into the curriculum framework is the fact that our school system lacks a subject that would systematically develop the moral side of pupils' personalities. The importance and current relevance of this step is also supported by the experience from most OECD countries, in which a subject with similar content is included in the education system.

The tradition of the community circle comes from the native inhabitants of North America, especially from the Midwest tribes. For centuries, indigenous peoples have used the circle to address personal and emotional issues. The members of the group usually sit in a circle that represents Mother Earth and the equality of all the members. Passing an object from speaker to speaker symbolizes the connection between the group members. The one who holds the objects speaks "from the heart" and the group listens quietly and discreetly until the speaker finishes his or her speech (Winters, 2014). The name is derived from the word community. In group psychotherapy, M. Scott Peck studied circle work in an adult community. He describes community as a group of individuals who have learned to communicate sincerely with each other in joy as well as in sorrow (Peck, 1995, p. 45). The Johnson siblings expand the use of the circle as a method of cooperative learning which should permeate school activities (1994).

\section{Theoretical basis}

Motyčka (2013) states that EtE can, at the beginning of its program, lead to the formation of self-perception and moral sensibilization, which naturally changes based on lifestyle and preferences. Sociometric research on aspects of prosocial behavior (Vaněk, 2011; Brestovanský et al., 2015) shows that EtE contributes to class satisfaction, cohesion, and development of self-evaluation. The circle supports mutual interaction among students and their participation in educational communication (Wannark, 2008). Vágnerová (2012) attributes an important period to pupils aged 11 to increase the ability to perceive emotional expressions and to attach importance to them. The closeness among the participants in education and their spatial orientation influence the possibility of their mutual interaction (Marx, Fuhrer, Hartig, 1999). The different layout allows them to see each other's faces and better understand the answers of their classmates. The teacher gives up his or her leadership position in the space and pupils can naturally communicate verbally and non-verbally. The teacher becomes a moderator of the discussion, thus his or her leading role is weakened. The aim of this method is to discuss. The community circle makes the class a community. The basic manifestation of the teacher's position in the circle may be his or her power to distribute communication channels by giving pupils space to speak and determining its length (Šed'ová, Sucháček, \& Majcík, 2015). The circle processes are based on equality between the participants and the principle of sharing power instead of having power over each other (Wilsons, 2000). Winters, in the US state of Illinois, has identified four phases of the community circle. The first phase is a connection, when icebreakers or sensibilization stories are included in the topic. It may include introduction of rules and instructions. The second phase is to define the topic in order to reveal personal connections with the topic. The third phase examines the problem and brings new ideas to the topic. It is possible to immerse deeper into the topic with use of appropriately chosen accompanying questions. The fourth phase is reflection, which strengthens the legacy of the topic, concluding consequences for one's own life, and evaluation of the topic benefits (Winters, 2014). Interpersonal intelligence, which includes group organization, negotiating solutions and conclusions, personal connections, and social analysis, are skills necessary for social success and personal attractivity. Such people then excel in professions where it is necessary to work closely with others (Goleman, 2011).

Clifford, the author of a methodology developed based on his many years of experience at a school in San Francisco, came up with the term Restorative circles. These should help teachers to create prosocial ties among classmates. His research with adolescents in a high school in California reveal that thanks to class circles, students have taken on more responsibility for their roles in problem solving. It was much easier to encourage the students to solve their own problems; "partly because I gained more confidence, students gained the 
necessary skills, but also the way we communicated shifted" (Clifford, 2016). Mr. and Mrs. Kopřiva deal with the topic of respectful communication as a suitable tool in designing agreement and rules with children. They recommend a communication procedure starting with a calm connection, a factual description of the topic, descriptive expression of the teacher's own expectations without unsolicited advice, expression of empathy with difficulties that have arisen, participation in the solution by expressing one's own opinion, the possibility of the student's choice of time and method of implementation of the agreements, respecting decisions, and transferring responsibility for implementation (Kopriva, 2015). The condition for fulfilling the goal of respecting the rules is to create a sense of security for every child which participates in the community circle. The community circle is a tool for the prevention of bullying and other social pathological phenomena, and it reduces disciplinary problems. Rules in a circle are created to ensure safety, order, and stability (Kopriva et al., 2015). The circle enables reflection of one's own attitudes because the pupils articulate their own attitude and get acquainted with the attitudes of their classmates and in such a way, these are confronted. In the community circle, the teacher gives up the main decision-making right and follows the common rules. With the ritual of passing an object, there is a rule related that only one person speaks at a time. The others listen to him or her. In case a student does not want to comment on the topic, his or her decision is respected. Pupils listen with respect and do not make fun of anyone. Information shared in the community circle remains there, it is private, and not told elsewhere (Kopřiva et al., 2015). The community circle develops relationships, creates community cohesion, a sense of belonging and acceptance for each pupil, the development of emotionality, and the creation of a safe classroom climate (Kopriva et al., 2015).

Bucci and his colleagues described other types of circles. The association circle is used to increase motivation for the topic, vocabulary development, creativity and communication development. The evaluation circle gives space for the evaluation of behavior or activity. The recommendation circle gives room for recommendations for behavior or activity. The appraisal circle gives room for appreciation of behavior or activity. The planning circle gives spaces for planning of activities. The discussion circle gives space for expressing one's thoughts and listening to opinions of the others. The reflective circle gives space for the expression of the transfer of ideas into personal lives (Bucci et al., 2017). This research focused on the community circle.

\section{Research methodology}

This paper is a partial output of a more extensive and broadly conceived research, which focused on various aspects and contexts of education and culture of a private family-type primary school. The case exploratory study, the subject of which are the teaching strategies of four respondents, focuses on the analysis of the activity of the community circle supporting communicative skill at the family-type primary school in the context of teaching prosociality. The aim of the conducted case study was to characterize how the processes of communication development in the community circle in EtE teaching are managed based on the observation of $4^{\text {th }}$ and $5^{\text {th }}$ grade and interviews with four teachers who teach in these classes. Qualitative research of a case exploratory study with one unit of analysis includes a method of direct observation of the lessons and semistructured interviews with four teachers.

The research took place at a Czech school, where EtE is implemented according to the school curriculum for all grades of primary and lower secondary school. The school has undergone many years of development of its teaching strategies in terms of methodology and content. The case is the teaching strategies of the teachers of the $4^{\text {th }}$ and $5^{\text {th }}$ grade. Four teachers who are directly involved in the teaching were selected for the research. The selection of the research sample of pupils from the two grades, i.e. $4^{\text {th }}$ and $5^{\text {th }}$ (the second period, according to the Curriculum framework) was targeted, so that the research reflected the results and outputs of teaching EtE from the $1^{\text {st }}$ to $3^{\text {rd }}$ grade (the first period, according to the Curriculum framework). The research methods were chosen to triangulate the results of in-depth semi-structured individual interviews with the teachers, direct observation of teaching with content analysis of the teaching artifacts and the school documents. Primary data were obtained through direct observations, audio recording of lessons and interviews with teachers from autumn 2019. The research continued during 2020. The following was formulated and described:

(1) What is the benefit of the community circle in the context of prosocial dialogue based on direct observation of teaching;

(2) What are the strategies of the teachers teaching communication in the community circle according to interviews with teachers; 
After transcription, the audio recording of the semi-structured interviews with the teachers were subjected to the extraction of significant verbal expressions addressing the central meaning of the segment. Direct speech is distinguished by signs for four respondents: U1, U2, U3, U4. Group segments are analyzed and interpreted. The segmented data with were analyzed with the intention of comparing the congruence of teachers' strategies with the actual teaching. The final coding scheme evaluates agreement in the following categories:

1. Completeness of support for learning prosocial communication

2. Number of opportunities for pupil's learning

3. Quality of teacher support for pupil's learning

4. Appropriateness of learning support

A qualitative data analysis was performed with the use of the MAXQDA program.

\section{RESULTS AND DISCUSSION}

\section{Benefit of the community circle for pupils based on direct observation of teaching in the context of the category of program support complexity}

For each item, the related final categories of the research coding scheme are indicated in parentheses.

1. The morning circle serves primarily to sensibilize the classroom, to release tension, and build a relationship between a teacher and pupils and among pupils (related to the category of number of opportunities for pupil's learning).

It can be a guided discussion, mutual sharing, and possibly also the use of short activities from the EtE field. It is during such teacher-pupils meetings, when the teacher is not "bound" by the teaching obligation, that the dynamics of the pupils' group in the classroom can shift in a positive direction and create a pleasant classroom climate (related to the category of appropriateness of learning support).

Classrooms are adapted so that the pupils have the opportunity to sit comfortably in a circle in which they can choose the place next to whom they will sit (related to the category of appropriateness of learning support).

In the community circle, the right to speak is given one by one, thus the pupils acquire self-control when they stop talking and let someone else speak. Moreover, perception and attention to what classmates are sharing is practiced. The next step is to try to understand the others and respect them the way they are. There is a practice of calm reactions and asking questions which are directly related to the discussed topic. Only then the discussion, constructive criticism, or stating of reasons and arguments of one's claims can take place.

2. Self-reflection, which is a strong point of the educational process, takes paces in the form of discussion in a circle (related to the category of appropriateness of learning support).

The pupils worked actively and creatively, and they were not afraid of questioning. They formulated their opinions. The teachers guided the pupils with simple questions to substantiate their claims. Why did you say that? How did you think of that? Why do you think this should be the case?

3. The communication style of the teachers with children in the community circle was very sensitive, kind, almost tender. The teachers try to understand the needs and interests of the pupils. They encourage pupils to express their opinion, discuss, seek optimal solution to various problems.

4. The quality of teaching in the community circle is in the support of free speech and the support of pupils' internal motivation (related to the category - quality of teacher support for pupil's learning). The pupils work in a community circle, where they have to agree on how to work together.

5. The teachers lead the pupils to be able to evaluate their own work on their own. They lead the pupils to realization of their strengths and weaknesses and to independence (related to the category of completeness of support for learning prosocial communication).

6. The teachers are convinced that, in fact, the ability to communicate well is one of the most important skills that children will need not only in their professional but also in their personal lives. Their work is authentic and "lived". Throughout this continuous process, it is crucial and desirable for the teacher to lead by example and respect the personality and temperament of the pupils. This way, the teacher helps to shape not only an individual pupil but also manifests his or her approach to others and thus shows the whole class the way to accept and respects the classmates (related to the category - quality of teacher support for pupil's learning). 
7. Continuous individual support of the teacher was a "matter of course" for the pupils. They turned to their teachers with great confidence, did not raise their hand, but immediately became engaged into the lesson with their questions. The teachers claimed that due to EtE teaching a positive classroom climate was developed. They also stated that they strategically include a daily evaluation circle in connection with evaluation of their work and the work of others (related to the category - quality of teacher support for pupil's learning).

8. By prosocial communication, the teachers give a natural model to follow and design processes for calm disagreement, solutions and agreement creations. Habits that lead to pupils' taking over of convening the circles to solve assignments or peer communication are emerging (related to the category completeness of support for learning prosocial communication).

\section{Circle rules in the context of quality and complexity of program support}

The circle should be regular. If this is not the case, the teacher lets the pupils know and asks them to correct it. At the school, four basic rules of the circle are followed. These are based on the recommendations in the book Respektovat a být respektován (Respect and Be Respected) (Kopřiva et al., 2015).

1. Listening is a skill that is one of the basic prerequisites for good relationships. It is a manifestation of respect for other people and it conditions successful communication. In short, this rule means - only one speaks, or the one with an object speaks (the passed object).

2. Right not to participate in the circle and not to speak can contribute to a sense of security. The pupil passes the right to speak on in a circle, and this expresses his or her involvement in the group. The right to refuse to speak on a topic teaches pupils to make decisions for themselves. The school intentionally offers space for pupils to experience the possibility of free choice. At the end of the circle, the opportunity to add what has been said is offered again.

3. The rule of respect applies to both verbal and non-verbal expressions. The pupils commit not to judge and not to criticize in a bad way.

4. The rule of privacy is important to maintain the need for security. The pupils can discuss the topic further, for example, with their parents, if they do not give the names of others. The description is therefore vague. For example, one boy/girl said that...

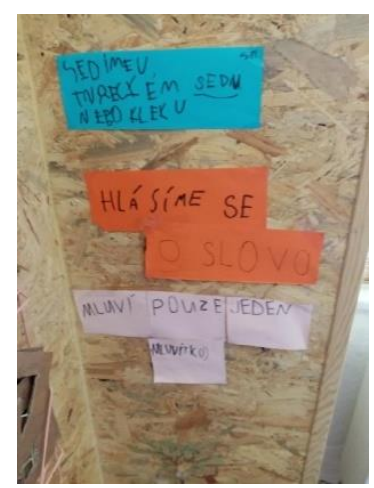

In the $1^{\text {st }}$ grade, some rules were written and hung on the wall so that the pupils could see them. The $4^{\text {th }}$ and $5^{\text {th }}$ graders did not have the rules of the circle shown because they are familiar to everyone. The pupils use the circle every day and do not need to have the rules recorded.

All four teachers equally express the need to acquire skills for sharing in a circle early, from the $1^{\text {st }}$ grade.

U4: "If we meet in a circle from the $1^{\text {st }}$ grade, it looks different. Not until the third grade, when it is said that there are layers of bad habits already."

U2: "There are more children this year and we have problems. We do everything to make ourselves feel good here together. It is obvious that they learn to solve problems in a circle together from the first grade and they can do it. It is visible in contrast to those that came later. Not everyone has to participate in the circle. If someone prefers to work at a desk, he or she works on his or her tasks. However, if one does not want to participate in the circle at the beginning, then one must not enter the debate later on or comment on anything. He or she does not have the right anymore." 


\section{Strategic creation of a space in a community circle for personal development of pupils according to statements of teachers in the context of the number of learning opportunities, quality, and complexity of program support}

1. Space for peer learning, strengthening social relations in the context of prosociality

U3: "Realized that the most important thing was face-to-face contact and communication. But we are learning that over and over again."

U2: "Now that there are the two new children, we will see again how much it helps us. That good old core in the class. How they are able to help the two in what they have been through themselves. These are things they have already learned and so they can help the newcomers to perceive them quickly in the class. Ours are able to pull them according to those common rules. Overall, it is introduced to the group. And the children take it as their own. In September (2020), it showed a lot now, so I thought it was about socialization that they are able to take care of others."

\section{Space for self-evaluation practice}

U2: "They have also progressed in the evaluation of themselves. Some a lot but some are on the way. When I saw them, how difficult it was for them to find something good about their work and now they praise it easily. But some still undervalue themselves. It is hard for them, but yeah, now they know how to evaluate themselves."

U3: "They have no problem evaluating their own work and usually express themselves very aptly."

U4: "Feedback with use of expanding question gives the teacher the opportunity to encourage the pupil to clarify their answer, substantiate it with evidence or illustrate in specific cases."

\section{Space for training of expressing emotions}

U4: "I think it helps them a lot what they say in the evaluation circle. Hearing the recognition from a classmate helps them a lot with motivation."

U3: "In the past, pupils had a bad reaction to recommendation when they received justified criticism. Now they know, there are good intentions and don't even say anything about it. It fits too. Feedback from pupils is always better and more accurate than from a teacher. They also absorb it better among themselves."

\section{Space for solving problems in a safe environment in compliance with respected rules}

U2: "The circles that the pupils convened by themselves during the breaks often concerned disputes among girls. They wanted to talk about it and I was supposed to be there as invited impartial person. But they solve it themselves. These girl circles are common. The girls learned to describe very well why they fell out with each other and look for a way out. They describe it nicely."

\section{The example of the teacher determines the direction of prosocial dialogue in the context of quality of program support}

It is appropriate for the teacher, as a model of prosocial behavior, to respect the personality and temperament of the pupils and thus show to the whole class the way to accept and respect the classmates. The natural way to master prosocial behavior is to observe and imitate the teacher's behavior. According to the teachers' statements, it seems that a teacher can consciously strengthen it or, on the contrary, inactivate prosocial behavior through inaction.

U1: "In the way children talk to each other in the classroom, there are your own shortcomings hidden. They absorb and immediately listen and imitate me."

The research brought the realization that teachers perceive the community circle as an aid to their own motivation for pedagogical work based on attributiveness, i.e. attributing good qualities to pupils.

U1: "Here, you just get to the stages where you see a lot more good qualities in the people around you than bad ones."

U1: "Actually, those children really behave the way I see them. And that's how it works. The attunement that I stop in front of the classroom and am looking forward to them putting the energy into it. That energy is flowing back at you twice. So it's a joy that it actually is like that." 
U1: "The kind of unrest has disappeared. It used to chase a lot that I should do this and that and on top of it, unappreciated. Now, I actually do the same things as twenty years ago but differently. It's a fact. I do it with love, differently."

The circle is an activity that is positively perceived by the teachers themselves for communication in the teachers' lounge.

U1: "At the school, we adults sit together in the circle as well. It's at least 4 times a year during supervision but if possible, we do it even more often. Now we would really need it again, I can actually physically feel it!"

\section{Space for personal development of teachers in the context of program complexity}

In the school, supportive factors which enable the development of prosocial habits are activated. These are, for instance, supervision, training, personal growth with a school mentor. The research reveals a conscious and effective approach of the teachers in EtE teaching which is unified at the school due to the active and systematic support of management.

U1: "The headmaster leads us a lot to this and uses it himself. I've been to those classes a few times to see it. I saw that the circle was not just manipulated. The circle gave the pupils a sense of security."

According to the teachers, the circle activity is beneficial for them as well because it gives them immediate feedback. The circle can be a kind of preventive measure to make a teacher fair to his or her pupils. Pupils are very sensitive to the teacher's attitudes.

U1: "The best characteristic a teacher can have is to accept pupils as they are and consider them all equally. For example, something in the class is going well, it's great and works, but for some pupils I'm kind of closed, I don't take him or her. That's the key. Because I have to tune the child with me. Well, and the children see this and they tune to each other that way. They can't not see it. It's that they actually live it openly."

\section{Limits of the community circle}

\section{Time limits}

The typology of primary school pupils is very broad and diverse. Distinguishing and respecting of the specific features of the pupil's personality is a necessary prerequisite for the cultivated development of his or her personality. An appropriate means for the development of a pupil's personality is the long-term and systematic development of communication skills. This takes, however, a lot of time. The respondents who are $4^{\text {th }}$ and $5^{\text {th }}$ grade class teachers stated that mutual support helps them the most.

U4: "We sit down together every day and talk about what went well. We discuss how to continue and what the children think about it. It takes a long time, but we see the meaning of that work and it helps us."

Despite its time-consuming nature, routine communication in a circle according to the rules is important in building and developing understanding, belonging, affection, agreement, and trust (Bucci, 2017). The teachers state that unnecessary stretching of sharing in a circle can be avoided, for example, by sharing some topics in pairs and then sharing one sentence in a circle. According to the teachers, the topic can be prepared in writing with pupils and the most important messages can be underlined etc.

\section{The readiness of the pupils to solve conflicts together in a circle limit}

It is important to differentiate when to use a circle and when it could lead to humiliation of one of the pupils. U1: "The circle must be prepared and mature so that pupils can solve breaking of the rules. It's tricky in a circle. For some, such a solution is not safe at all. It could be systematically humiliating. Some things must be done outside the circle. For example, it is good to deal with class leaders separately. Sometimes I divide them into boys' and girls' circles, and each of those energies is different." The communicative process with peers is an important element of peer social learning by which a pupil is continuously formed, and it is dependent on the number of pupils in the class. A smaller number of pupils is perceived by the teachers as an advantage, because they can pay more attention to the individual children. There are 16 pupils in the $4^{\text {th }}$ grade and 14 pupils in the $5^{\text {th }}$ grade. Even so, sharing activities in a circle is sometimes "long".

U3: "Sometimes it happens that after some time the circle annoys them. When they've been there a long time. I try to prevent it. Well, then when I see some of the kids, that they need to leave the circle for a while, they can walk around the class. It's up to them to see that they need the change."

U4: "If we have a Monday morning circle and we say how we were doing, I try to limit it somehow and everyone, for example, has only three sentences." 
3. Teacher maturity for circle modeling limit

The respondents have offers to teach in different schools, but they have consciously decided on this school even though there is an unusually large number of pedagogical meetings and appointments. For the adoption and confirmation of the habits of prosocial thinking the "lived" approached of the teachers is, therefore, important. By their behavior, they determine the concept of democratic behavior for the pupils.

The teacher should set an example in respecting declaration of their attitudes and opinions without attack. Kopriva (2015) describes utmost agreements on non-aggression in mutual minus emotional accounts. These agreements have in some cases been applied to group work. The tasks that are focused on cooperation lead to the inclusion of new pupils even in cases of mutual antipathy. According to the teachers, there are also difficulties with integrating new pupils at the school under study, waiting for pupils to tune in to the group. The teacher monitors when the new pupils accept the class rules enough to be ready to work in a circle.

U4: "I have to withdraw the circles and wait for the pupil to accept our rules, and only then can the conflicts be discussed and solved in a free democratic way, as we do it here."

\section{Final coding scheme of qualitative research}

The segmented data were analyzed with the intention of comparing the congruence of the teachers' strategies with the implemented teaching. The final coding scheme evaluates the agreement in the categories of completeness of support for prosocial communication learning, in the category of number of opportunities for pupil's learning, in quality of teacher support of pupil's learning and appropriateness of learning support. The following table describes the data obtained in each category.

Table 1: Final coding scheme

Categories of the final open coding scheme Description of obtained data

1. completeness of support for prosocial communication learning

2. category of number of opportunities for pupil's learning of prosocial communication in the circle

3. quality of teacher support for pupil's learning

4. appropriateness of learning support
The support of prosocial communication among classmates was complex on the part of teachers and was demonstrated throughout the whole day.

Support for creating opportunities for learning prosocial communication among classmates was demonstrated throughout the whole day.

The quality of teacher support for prosocial communication among classmates in the circle on the part of teachers was high. The teachers planned the inclusion of the circle and responded to the current needs of the pupils. They guided communication among the pupils by their own example but left the pupils freedom and space for their activities and agreements.

The support of prosocial communication was adequate to the age of the pupils. The teachers differentiated the method of support based on the individual needs of students. The teachers modeled prosocial communication in the community and thus appropriately created habits of calm and helpful communication. 
Source: own calculation

Subsequent research should be aimed at comparison of communicative habits in this school with a control group of pupils who have no experience with community circle learning. The level of pupils' self-evaluation, pupils' competitiveness, and the degree of friction and conflicts among pupils will be monitored by means of the $\mathrm{MCl}$ questionnaire modified by Laška (2001).

\section{Conclusion}

Based on direct observation of the teaching, it was found that the teachers try to promote mutual prosocial communication among classmates throughout the whole day. The targeted development of communication skills in the context of prosociality took place in a circle during the final evaluation, appreciation, recommendation, and peer teaching. Analysis of the obtained data at the school show that the pupils in the $4^{\text {th }}$ and $5^{\text {th }}$ grades are purposefully guided to the correct patterns of prosocial communication and to cooperation within the class during the evaluation in the community circle. The circles support cooperation and pupils' selfevaluation is encouraged.

The teachers expressed that they strategically include the activity of communication in the circle which, in their opinion, develops the ability to listen and share their knowledge with the class with confidence. According to the teachers, they facilitate teaching and help create a good school climate. In the interview, all the respondents agree that they are integrating the community circle more and more often because they are aware of its benefits in acquiring good communication habits. According to the respondents, the pupils developed the ability to empathize significantly.

In accordance with the expressed teachers' strategies with observation, the teachers organize space for the development of communicative skills in the context of prosociality. The school has undergone many years of development of the teaching and currently incorporates presentations, recommendations and recognition, and final reflections to the teaching in the community circle. The teacher is an advisor, coordinator and, above all, role model whose behavior the pupils imitate. A partial aim of the research is to capture details and describe the relationships and processes taking place in the microenvironment, which would lead to a better understanding in similar cases.

Subsequent research should be aimed to comparison of communicative habits in this school with a control group of pupils who have no experience with community circle learning. The level of pupils' self-evaluation, pupils' competitiveness, and the degree of frictions and conflicts among pupils will be monitored by means of the $\mathrm{MCl}$ questionnaire modified by Laška (2001).

\section{References}

[1] ČŠI. (2016) Tematická zpráva-Etická výchova v předškolním, základním a středním vzdělávání Doi: https://www.csicr.cz/cz/Dokumenty/Tematicke-zpravy/Tematicka-zprava-\%E2\%80\%93-Eticka-vychova-vpredskolnim,-z

[2] Bucci, D., Cannon, A., Ramkarran, A. (2017) Community Circlesand Collaboration: The First 10 Days Created for use at Armadale public school.

[3] Brestovanský, M., Sádovská, A., Podmanický, I., Kusý, P., (2015). Charakteristiky hodnotenia a sebahodnotenia prosociálneho správania u žiakov piatych a šiestych ročníkov vybraných základných škôl. Studia Paedagogica (20)1, p. 67-83.

[4] Clifford A., (2016) Teaching Restorative Practices with Classroom Circles, San Francisco :Center for Restorative Process Developed for Unified School District

[5] Escotorín, G., Roche, R. (2011) Cómo y por qué prosocializar la atención sanitaria: reflexiones, des-afíos y propuestas. Conclusiones del Proyecto Europeo CHANGE. La Garriga: Fundación Martì L’Humà.

[6] Goodman, R. (1997) The Strengths and Difficulties Questionnaire: A Research Note. "Journal of Child Psychology and Psychiatry“, Vol. 38, No. 5, pp. 581-586. 
[7] Kopřiva, P., Kopřivová, T., Nevolová, D., Nováčková, J. (2015) Respektovat a být respektován. Kroměříž: Spirála.

[8] Johnson, D. W. \& Johnson, R. T. (2009) An Educational Psychoogy Success Story: Social Interdependence Theory and Cooperative Learning. Educational Researcher. 38(5), 365-379. Doi: https://www.researchgate.net/publication/228634517_An_Educational_Psychology_Success_Story_Socia I_Interdependence_Theory_and_Cooperative_Learning

[9] Marx, A., Furher, U., Harting, T., (1999) Learning Environments Research, Springer

[10] Motyčka, P., (2013). Implementace doplňujícího vzdělávacího oboru Etická výchova v České republice. Pedagogická fakulta, UK: Praha Doi: https://is.cuni.cz/webapps/zzp/detail/93244/

[11] Peck, M., S., (1995). V jiném rytmu. Olomouc: Votobia.

[12] Podmanický, I., Rajský, A. (2016). Človek človeku. K prameňom etickej výchovy. Trnava: Typi Universitatis Tyrnaviensis

[13] Rajský, A. (2019). Love as absolute challenge - Also for education. Kultura i Wychowanie. 2. 89-98.

[14] Stará, J., 2011. Výzkumy souladu záměru vzdělávacích programů s jejich implementací. Pedagogika, 3, s. 290 - 305.

[15] Roche, R., O., (1992). Etická výchova. 1. vyd. Bratislava: Orbis Pictus Istropolitana.

[16] Roche, R., O., (2003). Rozvoj prosociální inteligence. Základní program pro zvýšení míry prosociálnosti.Celostátní seminář Etická výchova, Kroměříž, 14.-16. listopadu 2003.

[17] Roche, R. O. (2005). Prosociálnost jako princip účinného projektu etické výchovy dětí a mládeže. Výňatek z přednášek roku 2003. In Kolektiv autorů,Na cestě s etickou výchovou. Sborník přednášek semináře $S$ etickou výchovou do sjednocené Evropy, Kroměřǐz: Luxpress.

[18] Šed'ová, K., Šalamounová, Z., Švaříček R., Sedláček, M., (2020). Getting Dialogic Teaching into Classrooms. Making Change Possible. Heidelberg: Springer, 2020. 184 pp.

[19] Vágnerová, M., (2012) Vývojová psychologie: dětství a dospívání. Vyd. 2., rozš. a přeprac. Praha: Karolinum.

[20] Vaněk, D., (2011). Etická výchova - možnost rozvoje prosociálního chování u žáků 2. stupně základní školy. Paidagógos, 1, s. $28-41$.

[21] Wannarka, R., Ruhl, K. (2008). Seating arrangements that promote positive academic and behavioural outcomes: A review of empirical research. Support for Learning, 23(2), 89-93.

[22] Winters, A. (2014). Using Talking Circles in the Classroom. Heartland Community College, 1.

[23] Wilson, P., Wilson, S., (2000). Circles in the classroom: the cultural significance of structure, Social Studies: North York Sv. 34, Čís. 2, Winter: 11-12. 